\title{
MAPPING PERKEMBANGAN PEMIKIRAN FIQH KONTEMPORER KEUANGAN DAN PERBANKAN
}

\author{
Muhammad Yusuf \\ Institut agama Islam Negeri (IAIN) Mataram
}

\begin{abstract}
Abstrak
Pada tataran konseptual pemikiran fiqih kevangan dan perbankan memuculkan sebuah perdebatan bahwasanya kedua konsep tersebut terlahir sebagai sesuatu yang baru dalam kajian keislaman ataukah suatu konsep lama yang mengalami pembaharuan daban atau temuan baru dalam kajian kekinian sebagai bentuk ijtihad ummat islam masa kini. Perjalanan sejarah mengarahkan kepada kita untuk mengetahui bahwa ekonomi Islam yang didalamnya terdapat konsep kevangan dan perbankan, telah kehilangan pengakuan selama masa kemunduran hingga masa modernis. Begitu juga permasalahan-permasalahan yang terkait dengan ikhtilaf para ulama terkait dengan keberadaan lembagalembaga keuangan Islam modern saat ini, yang terus menuai kritik dikalangan masyarakat banyak. Kendati demikian, sistem ekonomi Islam setidaknya mempunyai ciri khas dibanding sistem ekonomi lainnya (kapitalis-sosialis).
\end{abstract}

Kata Kunci: Keuangan. Bank. Ekonomi Islam.

\section{A. PENDAHULUAN}

Perjalanan sejarah mengarahkan kepada kita untuk mengetahui bahwa ekonomi Islam yang didalamnya terdapat konsep keuangan dan perbankan, telah kehilangan pengakuan selama masa kemunduran hingga masa modernis. Hingga tiba saatnya terjadi upaya pengakuan kembali, setelah adanya pernyataan parakaum cendekiawanbahwakonsep rumusan ekonomi Islam yang telah digagas para ulama’ masa keemasan ketika Islam mengalami zaman kemunduran telah dilakukan tindak plagiatisme terhadap banyak segi keilmuannya. Menurut Umer Chapra, meskipun sebagian kesalahan terletak di tangan umat Islam karena tidak mengartikulasikan secara memadai kontribusi kaum muslimin, namun Barat memiliki andil dalam hal ini, karenatidakmemberikanpenghargaan yang layak atas kontribusi peradaban lain bagi kemajuan pengetahuan manusia. ${ }^{1} \quad$ Kontribusi kaum muslimin yang sangat besar terhadap

${ }^{1}$ Chapra, Umar, 2004, "The Future of Ec nomic: An islamic Perspective", STEI SEBI, Jakarta, hal. 10 
kelangsungan dan perkembangan pemikiran ekonomi pada khususnya dan peradaban dunia pada umumnya, telah diabaikan oleh para ilmuwan Barat. Buku-buku teks ekonomi Barat hampir tidak pernah menyebutkan peranan kaum muslimin didalamnya.

Membicarakan ekonomi Islam secara utuh dan terurai dengan rinci, tidak cukup dikemukakan pada tulisan yangsempitini, karena sistem ekonomi Islam mencakup beberapa dimensi dari konsep ekonomi itu sendiri dan mempunyai ketergantungan dengan beberapa disiplin ilmu lainnya sebagaimana juga yang ditemukan pada studi ekonomi umum. Persolan sistem bank syariah misalnya, hanyalah sebagian kecil dari sederetan masalah-masalah yang terdapat dalam studi ekonomi, keuangan dan perbankan syariah. Begitu juga permasalahan-permasalahan yang terkait dengan ikhtilaf para ulama terkait dengan keberadaan lembagalembaga keuangan Islam modern saat ini, yang terus menuai kritik dikalangan masyarakat banyak. Kendati demikian, sistem ekonomi Islam setidaknya mempunyai ciri khas dibanding sistem ekonomi lainnya (kapitalis-sosialis). Dr. Yusuf Qardhawi, mengemukakan dalam karyanya "Daurul Qiyam wal akhlaq fil iqtishad al-Islamy" menjelaskan empat ciri-ciri ekonomi Islam, yaitu ekonomi robbani, ekonomi akhlaqy, ekonomi insani dan ekonomi wasati. Keempat ciri tersebut mengandung pengertian bahwa ekonomi Islam bersifat robbani, menjunjung tinggi etika, menghargai hak-hak kemanusiaan dan bersifat moderat. $^{2}$

\section{B. PERKEMBANGANPEMIKIRAN FIQIH KEUANGAN DAN PERBANKAN PERSPEKTIF SEJARAH}

Cakupan ajaran Islam yang meliputi seluruh aspek hidup manusia, yang didalamnya membahas tentang institusi keuangan dan bank walaupun di zaman Nabi SAW belum, tetapi ajaran Islam sudah memberikan prinsip-prinsip dan filosofi dasar yang harus dijadikan pedoman dalam aktifitas perdagangan dan perekonomian. Menghadapi masalah muamalah kontemporer yang harus dilakukan hanyalah mengidentifikasi prinsip-prinsip dan filosofi dasar ajaran Islam dalam bidang ekonomi, dan kemudian mengidentifkasi semua hal yang dilarang. Setelah kedua hal ini dilakukan, maka dapat dilakukan inovasi dan kreativitas (ijtihad) seluasluasnya untuk memecahkan segala persoalan muamalah kontemporer, termasuk persoalan keuangan dan perbankan.

Namun, sebelum "proses ijtihad" dalam persoalan perbankan ini dilakukan, ada baiknya meneliti terlebih dahulu apakah persoalan keuangan dan perbankan ini benarbenar merupakan suatu persoalan yang baru bagi umat Islam atau bukan. Apakah konsep "bank" merupakan konsep yang asing dalam

${ }^{2}$ Qardhawi, Yusuf, 1995, Daurul Qiyam wal akhlaq fil iqtishad al-Islamy, (Norma dan Etika Ekonomi Islam) oleh Zainal Arifin dan Dahlia Husein, Gema Insani Press, Jakarta, hal. 33. 
sejarah perekonomian umat Islam? Pertanyaan ini amat penting untuk dijawab karena akan menentukan langkah kita selanjutnya. Bila konsep keuangan dan bank adalah konsep yang baru bagi umat Islam, maka harus di mulai langkah ijtihad dari nol. Namun, bila konsep keuangan dan bank bukan konsep yang baru, artinya umat Islam sudah mengenal bahkan mempraktekkan fungsi-fungsi keuangan dan perbankan dalam kehidupan perekonomiannya, maka proses ijtihad yang harus dilakukan tentunya akan menjadi lebih mudah. Hal ini akan memberikan jawaban atas pertanyaan di atas, dengan menelusuri secara singkat praktekpraktek keuangan dan perbankan yang dilakukan oleh umat muslim sepanjang sejarah.

\section{Praktek Keuangan dan Perbankan} Di Zaman Nabi Saw Dan Sahabat

Keuangan dan perbankan adalah salah satu lembaga yang melaksanakan tiga fungsi utama, yaitu menerima simpanan uang, meminjamkan uang, dan memberikan jasa pengiriman uang. Di dalam sejarah perekonomian kaum muslimin, pembiayaan yang dilakukan dengan akad yang sesuai syariah telah menjadi bagian dari tradisi umat Islam sejak zaman Rasulullah saw. Praktek-praktek seperti menerima titipan harta, meminjamkan uang untuk keperluan konsumsi dan untuk keperluan bisnis, serta melakukan pengiriman uang, telah lazim dilakukan sejak zaman Rasulullah. Dengan demikian, fungsifungsi utama keuangan dan perbankan modern yaitu menerima deposit, menyalurkan dana, dan melakukan transfer dana telah menjadi bagian yang tidak terpisahkan dari kehidupan umat Islam, bahkan sejak zaman Rasulullah saw.

Rasulullah SAW yang dikenal dengan julukan al-Amin, dipercaya oleh masyarakat Mekah menerima simpanan harta, sehingga pada saat terakhir sebelum Rasul hijrah ke Madinah, beliau meminta Sayyidina Ali ra untuk mengembalikansemuatitipanitukepada yang memilikinya. ${ }^{3}$ Dalam konsep ini, yang dititipi tidak dapat memanfaatkan harta titipan tersebut. Seorang sahabat Rasulullah, Zubair bin al Awwam, memilih tidak menerima titipan harta. Beliau lebih suka menerimanya dalam bentuk pinjaman. Tindakan Zubair ini menimbulkan implikasi yang berbeda: pertama, dengan mengambil uang itu sebagai pinjaman, beliau mempunyai hak untuk memanfaatkannya; kedua, karena bentuknya pinjaman, maka ia berkewajiban mengambalikannya utuh. ${ }^{4}$ Sahabat lain, Ibnu Abbas tercatat melakukan pengiriman uang ke Kufah. Juga tercatat Abdullah bin Zubair di Mekah juga melakukan pengiriman uang ke adiknya Misab bin Zubair yang tinggal di Irak. Pemberian modal untuk modal kerja berbasis bagi hasil, seperti mudharabah, musyarakah, muzara'ah, musaqah, telah dikenal sejak awal

${ }^{3}$ Sami Hamoud, 1985, Islamic Banking, Ar bian Information Ltd, London.

${ }^{4}$ Sudin Haron, 1996, Prinsip dan Operasi Perbankan Islam, Berita Publishing Sdn Bhd, Kuala Lumpur. 
diantara kaum Muhajirin dan kaum Anshar. ${ }^{5}$

Jelasnya bahwa ada individuindividu yang telah melaksanakan fungsi keuangan dan perbankan di zaman Rasulullah saw, meskipun individu tersebut tidak melaksanakan seluruh fungsi keuangan dan perbankan. Ada sahabat yang melaksanakan fungsi menerima titipanharta, ada sahabatyang melaksanakan fungsipinjam-meminjam uang, ada yang melaksanakan fungsi pengiriman uang, dan ada pula yang memberikan modal kerja.

Beberapa istilah keuangan dan perbankan modern bahkan berasal dari khazanah ilmu fiqih, seperti istilah kredit (Inggris: credit; Romawi: credo) yang diambildariistilahqard.Creditdalambahasa Inggris berarti meminjamkan uang; credo berarti kepercayaan; sedangkan qard dalam fiqih berarti meminjamkan uang atas dasar kepercayaan. Begitu pula istilah cek (Inggris: check; Perancis: cheque) yang diambil dari istilah saq (suquq). Suquq dalam bahasa Arab berarti pasar, sedangkan cek adalah alat bayar yang biasa digunakan di pasar.

\section{Praktek Keuangan dan Perbankan Di Zaman Bani Umayyah Dan Bani Abbasiyah}

Institusi keuangan dan bank tidak dikenal dalam kosa kata fikih Islam, karena memang institusi ini tidak dikenal oleh masyarakat Islam di masa Rasulullah, Khulafaur Rasyidin, Bani Umayyah, maupun Bani Abbasiyah. Namun fungsi-fungsi keuangan dan perbankan yaitu menerima deposit, menyalurkan dana telah lazim dilakukan, tentunya dengan akad yang sesuai syariah.

Di zaman Rasulullah saw fungsi-fungsi tersebut dilakukan oleh perorangan, dan biasanya satu orang hanya melakukan satu fungsi saja. Baru kemudian, di zaman Bani Abbasiyah, ketiga fungsi keuangan dan perbankan dilakukan oleh satu individu. Fungsifungsi keuangan dan perbankan yang dilakukan oleh satu individu, dalam sejarah Islam telah dikenal sejak zaman Abbasiyah. ${ }^{6}$ Keuangan dan perbankan mulai berkembang pesat ketika beredar banyak jenis mata uang pada zaman itu, sehingga perlu keahlian khusus untuk membedakan antara satu mata uang denganmatauanglainnya. Inidiperlukan karena setiap mata uang mempunyai kandungan logam mulia yang berlainan sehingga mempunyai nilai yang berbeda pula. Orang yang mempunyai keahlian khusus ini disebut naqid, sarraf, dan jihbiz. Hal ini merupakan cikalbakal praktek penukaran mata uang (money changer). Istilah jihbiz mulai dikenal sejak zaman Muawwiyah (661$680 \mathrm{M})$ yang sebenarnya dipinjam dari bahasa Persia, kahbad atau kihbud. Pada masa pemerintahan Sasanid, istilah ini dipergunakan untuk orang yang ditugaskan mengumpulkan pajak tanah.

Peranan institusi keuangan dan perbankan pada zaman Abbasiyah mulai populer pada pemerintahan Muqtadir

${ }^{6}$ Adiwarman Karim, 2001, "Bankir Yahudi pada Zaman Abbasiyah”, Ekonomi Islam Suatu Kajian Kontemporer, Gema Insani Press, Jakarta, hal. 20 
(908-932M). Saat itu, hampir setiap wazir mempunyai bankir sendiri. Misalnya, Ibnu Furat menunjuk Harun ibnu Imran danJosephibnuwahab sebagaibankirnya. Lalu Ibnu Abi Isa menunjuk Ali ibn Isa, Hamid ibnu Wahab menunjuk Ibrahim ibn Yuhana, bahkan Abdullah al-Baridi mempunyai tiga orang bankir sekaligus: dua Yahudi dan satu Kristen. ${ }^{7}$

Kemajuan praktek keuangan dan perbankan pada zaman itu ditandai dengan beredarnya saq (cek) dengan luas sebagai media pembayaran. Bahkan, peranan bankir telah meliputi tiga aspek, yakni menerima deposit, menyalurkannya, dan mentransfer uang. Dalam hal yang terakhir ini, uang dapat ditransfer dari satu negeri ke negeri lainnya tanpa perlu memindahkan fisik uang tersebut. Para pelaku money changer yang telah mendirikan kantor-kantor di banyak negeri telah memulai penggunaan cek sebagai media transfer uang dan kegiatan pembayaran lainnya. Dalam sejarah keuangan dan perbankan, adalah Sayf alDawlah al-Hamdani yang tercatat sebagai orang pertama yang menerbitkan cek untuk keperluan kliring antara Baghdad (Irak) dan Aleppo (Spanyol sekarang). ${ }^{8}$

Uraian tersebut memberikan gambaran bahwa pada dasarnya praktik-praktik riil terkait dengan aktivitas keuangan dan perbankan memang telah dianggap menjadi bagian hidup masyarakat muslim pada saat itu. Berdasarkan uraian terkait

${ }^{7}$ Ibid hal. 31

${ }^{8}$ Sudin Haron, 1997, Islamic Banking: Rules and Regulations, Pelanduk Publications, Petaling Jaya, hal. 2. Lihat dalam Sami Hassan Homoud, 1994, Progress of Islamic Banking: The Aspirations and the Realities. Islamic Economic Studies, Vol. 2 No. 1, December, hal. 71-80. perkembangan fiqh keuangan dan perbankan perspektif sejarah dapat digambarkan sebagai berikut:

\begin{tabular}{|c|c|c|}
\hline Fase & $\begin{array}{r}\text { Perkembar } \\
\text { Ekonomi, } \\
\text { Per }\end{array}$ & $\begin{array}{l}\text { gan Pemikiran } \\
\text { Keuangan dan } \\
\text { ankan }\end{array}$ \\
\hline $\begin{array}{c}\text { Fase I } \\
(\text { Abad } \\
11 \mathrm{M} / \\
5 \mathrm{H})\end{array}$ & $\begin{array}{l}\text { - Zaid bin } \\
\text { Ali } \\
(80 \mathrm{H} / 738 \\
\mathrm{M}) \\
\\
\text { - Abu } \\
\text { Hanifah } \\
\text { (150 } \\
\text { H/ } 767 \mathrm{M}) \\
\\
\text { - Abu Yusuf } \\
\text { (182 } \\
\text { H/ } 798 \mathrm{M})\end{array}$ & $\begin{array}{l}\text { - Keabsahan } \\
\text { jual beli } \\
\text { secara } \\
\text { tangguh } \\
\text { dengan } \\
\text { harga yang } \\
\text { lebih tinggi } \\
\text { daripada jual } \\
\text { beli secara } \\
\text { tunai. } \\
\text { - Jual beli } \\
\text { salam } \\
\text { - Pembelaan } \\
\text { hak-hak } \\
\text { ekonomi } \\
\text { kaum lemah. } \\
\text { - Keuangan } \\
\text { Publik } \\
\text { - Pembentukan } \\
\text { dan } \\
\text { pengendalian } \\
\text { harga } \\
\text { - Konsep kerja } \\
\text { - Perilaku } \\
\text { konsumen } \\
\text { dan produsen } \\
\text { - Spesialisasi } \\
\text { dan distribusi } \\
\text { pekerjaan } \\
\text { - Konsep uang }\end{array}$ \\
\hline
\end{tabular}




\begin{tabular}{|c|c|c|}
\hline $\begin{array}{c}\text { Fase II } \\
(\text { Abad } \\
11-15 \\
\mathrm{M})\end{array}$ & $\begin{array}{l}\text { - Ibnu } \\
\text { Taimiyah } \\
(728 \\
\mathrm{H} / 1328 \\
\mathrm{M}) \\
\\
\\
\text { - Ibnu } \\
\text { Khaldun } \\
\text { (808 } \\
\mathrm{H} / 1406 \\
\mathrm{M})\end{array}$ & 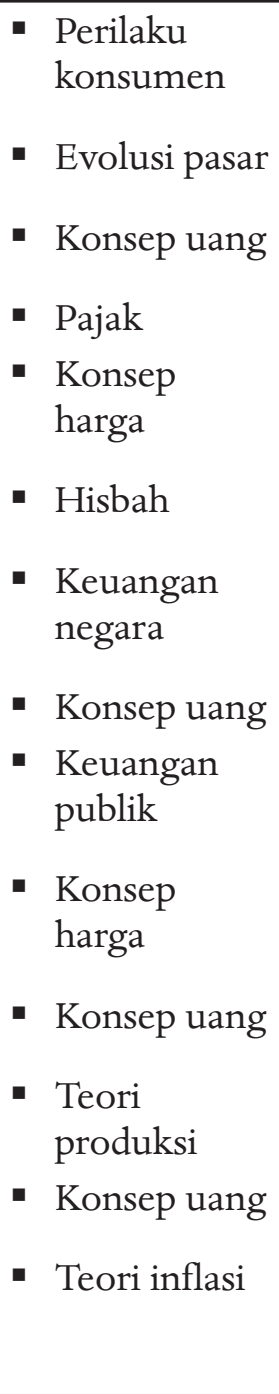 \\
\hline
\end{tabular}

Dengan demikian mapping perkembangan fiqh keuangan dan perbankan pada awal sejarahnya telah muncul di masa awal Islam, klasik hingga masa pertengahan, hal ini membantu untuk mengurai peta perkembangan fiqh mu'asir keuangan dan perbankan pada masa modern sampai pada saat ini.

\section{ANALISIS DAN MAPPING PERKEMBANGANPEMIKIRAN FIQH MU'ASIR KEUANGAN DAN PERBANKAN}

Perkembanganfiqhkontemporer keuangan dan perbankan selanjutnya adalah kegiatan yang dilakukan oleh perorangan jihbiz kemudian dilakukan oleh institusi yang saat ini dikenal sebagai institusi keuangan dan bank. Ketika bangsa Eropa mulai menjalankan praktek keuangan dan perbankan, persoalan mulai muncul karena transaksi yang dilakukan menggunakan instrumen bunga yang dalam pandangan fikih adalah riba, dan oleh karenanya haram. Transaksi berbasis bunga ini semakin merebak ketika Raja Henry VIII pada tahun 1545 membolehkan bunga (interest) meskipun tetap mengharamkan riba (usury) dengan syarat bunganya tidak boleh berlipat ganda (excessive). Ketika Raja Henry VIII wafat, ia digantikan oleh Raja Edward VI yang membatalkan kebolehan bunga uang. Ini tidak berlangsung lama. Ketika wafat,iadigantikanoleh RatuElizabeth I yang kembali membolehkan bunga uang. ${ }^{9}$

Selanjutnya, bangsa Eropa mulai bangkit dari keterbelakangannya dan mengalami renaissance. Penjelajahan dan penjajahan mulai dilakukan ke seluruh penjuru dunia, sehingga kegiatan perekonomian dunia mulai didominasi oleh bangsa-bangsa Eropa. Padasaatyangsama, peradabanmuslim mengalami kemerosotan dan negara-

${ }^{9}$ Adiwarman Karim, 2001, "Ketika Riba Me jadi Bunga”, Gema Insani Press, Jakarta, hal. 46 
negara muslim satu per satu jatuh ke dalam cengkeraman penjajahan bangsa-bangsa Eropa. Akibatnya, institusi-institusi perekonomian umat muslim runtuh dan digantikan oleh institusi ekonomi bangsa Eropa. Keadaan ini berlangsung terus sampai zaman modern kini. Karena itu, institusi keuangan dan perbankan yang ada sekarang di mayoritas negaranegara muslim merupakan warisan dari bangsa Eropa, yang notabene berbasis bunga.

Sistem ekonomi Islam yang didalamnya terdapat unsur keuangan dan perbankan bukanlah hal baru sama sekali. Namun patut diakui bahwa sistem yang pernah berjaya ini pernah tenggelam dalam masa yang cukup lama, dan sempat dilupakan oleh sementara pihak, karena kuatnya dua sistem yang pernah berebut simpati dunia yaitu sistem kapitalisme dan sosialisme. Sistem ekonomi Islam mengalami perkembangan sejarah baru pada era kontemporer. Menurut Khurshid Ahmad, ada empat tahapan perkembangan dalam wacana pemikiran ekonomi Islam kontemporer ${ }^{10}$, yaitu:

\section{Tahapan Pertama,}

Tahap perkembangan pertama dimulai ketika sebagian ulama, yang tidak memiliki pendidikan formal dalam bidang ilmu ekonomi namun memiliki pemahaman

${ }^{10}$ Ahmad, Khursid. 2001. "Kata Pengantar" dalam Umer Chapra (2001), Masa Depan Ilmu Ekonomi: Sebuah Tinjauan Islam/The Future of Economics: An Islamic Perspective. Ikhwan Abidin Basri (terj.) Jakarta: Gema Insani Press, hal.30 terhadap persoalan-persoalan sosioekonomi pada masa itu, mencoba untuk menuntaskan persoalan bunga. Mereka berpendapat bahwa bunga bank itu haram dan kaum muslimin harus meninggalkan hubungan apapun dengan perbankan konvensional. Masa ini dimulai kirakira pada pertengahan dekade 1930-an dan mengalami puncak kemajuannya pada akhir dekade 1950-an dan awal dekade 1960-an. Pada masa itu di Pakistan didirikan bank Islam lokal yang beroperasi bukan pada bunga. Sementara itu di Mesir juga didirikan lembaga keuangan yang beroperasi bukan pada bunga bernama Mit Ghomir Local Saving. Tahapan ini memang masih bersifat prematur dan coba-coba sehingga dampaknya masih sangat terbatas. Meskipun demikian tahapan ini telah membuka pintu lebar bagi perkembangan selanjutnya.

Namun sayang, karena terjadi kekacauan politik di Mesir maka Mit Ghamr mulaimengalamikemunduran, sehingga operasionalnya diambil alih oleh National Bank of Egypt dan bank sentral Mesir pada 1967. Pengambilalihan ini menyebabkan prinsip nirbunga pada Mit Ghamr mulai ditinggalkan, sehingga bank ini kembali beroperasi berdasarkan bunga. Pada 1971 akhirnya konsep nir-bunga kembali dibangkitkan pada masa rezim Sadat melalui pendirian Nasser Social Bank. Tujuan bank ini adalah untuk menjalankan kembali bisnis yang berdasarkan konsep yang telah dipraktekkan oleh Mit Ghamr. ${ }^{11}$

${ }^{11}$ Ibid, hal. 31-34. 
Kesuksesan Mit Ghamr ini memberi inspirasi bagi umat muslim di seluruh dunia, sehingga muncullah kesadaran bahwa prinsipprinsip Islam ternyata masih dapat diaplikasikan dalam bisnis modern. Ketika OKI akhirnya terbentuk, serangkaian konferensi internasional mulai dilangsungkan, di mana salah satu agenda ekonominya adalah pendirian bank Islam. Akhirnya terbentuklah Islamic Development Bank (IDB) pada bulan Oktober 1975 yang beranggotakan 22 negara Islam pendiri. Bankini menyediakan bantuan finansial untuk pembangunan negaranegara anggotanya, membantu mereka untuk mendirikan bank Islam di negaranya masing-masing, dan memainkan peranan penting dalam penelitian ilmu ekonomi, perbankan dan keuangan Islam. Kini, bank yang berpusat di Jeddah-Arab Saudi itu telah memiliki lebih dari 43 negara anggota.

\section{Tahapan kedua}

Tahap perkembangan kedua dimulai pada akhir dasa warsa 1975-an. Pada tahapan ini para ekonom Muslim yang pada umumnya dididik dan dilatih di perguruan tinggi terkemuka di Amerika Serika dan Eropa mulai mencoba mengembangkan aspekaspek tertentu dari sistem moneter Islam. Mereka melakukan analisis ekonomi terhadap larangan riba (bunga) dan mengajukan alternatif perbankan yang tidak berbasis bunga. Serangkaian konferensi dan seminar internasional tentang ekonomi dan keuangan Islam digelar beberapa kali dengan mengundang para pakar, ulama, ekonom baik muslim maupun non-muslim. Konferensi internasional pertamatentangekonomiIslam digelar di Makkah al-Mukarromah pada tahun 1976 yang disusul kemudian dengan konferensi internasional tentang Islam dan Tata Ekonomi Internasional yang baru di London pada tahun 1977. Setelah itu digelar berbagai seminar tentang Ekonomi Moneter dan Fiskal serta Perbankan Islam di berbagai negara.

Pada tahapan kedua ini, yang dalam gambaran perkembangan pemikiran Islam terkait dengan perkembangan ekonomi masuk dalam fasekeIII, muncul nama-nama ekonom muslim terkenal di seluruh dunia Islam antara lain Prof. Dr. Khurshid Ahmad yang dinobatkan sebagai bapak ekonomi Islam, Dr. M. Umer Chapra, Dr. M. A. Mannan, Dr. Omar Zubair, Dr. Ahmad An-Najjar, Dr. M. Nejatullah Siddiqi, Dr. Fahim Khan, Dr. Munawar Iqbal, Dr. Muhammad Ariff, Dr. Anas Zarqa dan lain-lain. Mereka adalah ekonom muslim yang dididik di Barat tetapi memahami sekali bahwa Islam sebagai way of life yang integral dan komprehensif memiliki sistem ekonomi tersendiri dan jika diterapkan dengan baik akan mampu membawa umat Islam kepada kedudukan yang berwibawa di mata dunia. Dengan demikian dapat digambarkan bahwa pemetaan tokoh pemikir Islam pada tahapan pertama dan tahapan kedua merupakan fase ke III dimulainya gerakan pembaharuan atau kebangkitan kembali dunia Islam 
dalam bidang ekonomi, keuangan dan perbankan.

\begin{tabular}{|c|c|}
\hline Fas & $\begin{array}{c}\text { Perkembangan Pemikiran } \\
\text { Ekonomi, Keuangan dan Perbankan }\end{array}$ \\
\hline 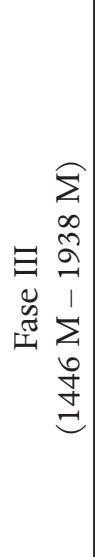 & $\begin{array}{lll}\text { Shah Waliullah } & \text { G e r a k a } \mathrm{n} \\
(1176 \mathrm{H} / 1762 \mathrm{M}) & \text { pembaharu pada } \\
& \text { dua abad terakhir } \\
\text { J a m a l u d i n } & \text { yang } & \text { menyeru } \\
\text { a l- A f g h a n i } & \text { untuk } & \text { kembali } \\
(1315 \mathrm{H} / 1897 \mathrm{M}) & \text { kepada } & \text { Al-Quran } \\
& \text { dan } & \text { al-Hadis } \\
\text { M u h a m a d } & \text { sebagai pedoman } \\
\text { A b d u h hidup. } & \\
(1320 \mathrm{H} / 1905 \mathrm{M}) & \\
& \\
\text { MuhammadIqbal } & \\
(1357 \mathrm{H} / 1938 \mathrm{M}) & \end{array}$ \\
\hline 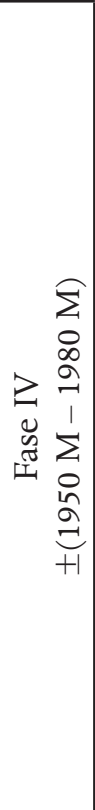 & 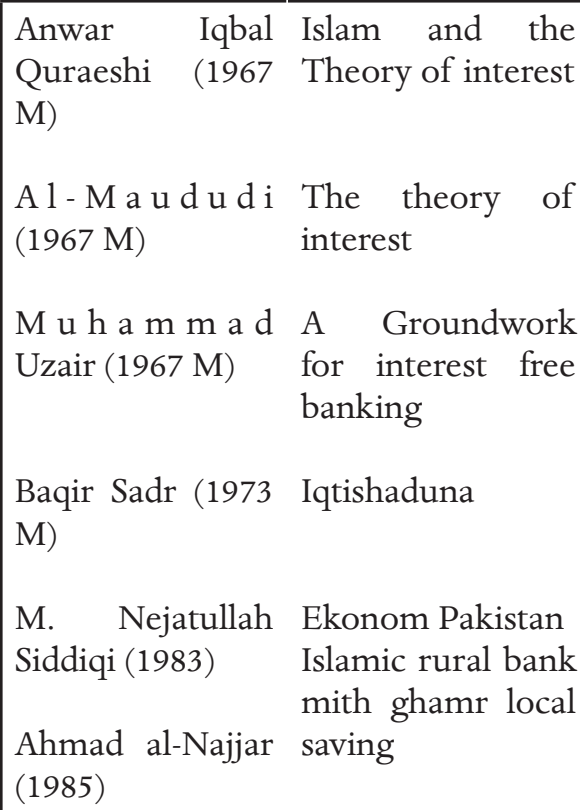 \\
\hline
\end{tabular}

3. Tahapan ketiga

Tahap perkembangan ketiga ditandai dengan upaya-upaya konkrit untuk mengembangkan perbankan dan lembaga-lembaga keuangan nonriba baik dalam sektor swasta maupun dalam sektor pemerintah. Tahapan ini merupakan sinergi konkrit antara usaha intelektual dan material para ekonom, pakar, banker, para pengusaha dan para hartawan muslim yang memiliki kepedulian kepada perkembangan ekonomi Islam. Pada tahapan ini sudah mulai didirikan bank-bank Islam dan lembaga investasi berbasis non-riba dengan konsep yang lebih jelas dan pemahaman ekonomi yang lebih mapan. Bank Islam yang pertama kali didirikan adalah Islamic Development Bank (IDB) pada tahun 1975 di Jeddah, Saudi Arabia.

Pada perkembangan selanjutnya di era 1970-an, usaha-usaha untuk mendirikan bank Islam mulai menyebarke banyak negara. Beberapa negara seperti Pakistan, Iran dan Sudan, bahkan mengubah seluruh sistem keuangan di negara itu menjadi sistem nir-bunga, sehingga semua lembaga keuangan di negara tersebut beroperasi tanpa menggunakan bunga. Di negara Islam lainnya seperti Malaysia dan Indonesia, bank nir-bunga beroperasi berdampingan dengan bank-bank konvensional. Kini, perbankan syariah telah mengalami perkembangan yang cukup pesat dan menyebar ke banyak negara, bahkan ke negara- negara Barat. The Islamic Bank International of Denmark tercatat sebagai bank syariah pertama yang beroperasi di Eropa, yakni pada tahun 1983 di Denmark. ${ }^{12}$ Kini, bank-bank besar dari negara-negara Barat seperti Citibank, ANZBank, Chase Manhattan Bank dan Jardine Fleming telah pula membuka Islamic window agar dapat

${ }^{12} \mathrm{Mr}$. Erik Trolle-Schultz, 1986, How the First Islamic Bank was Established in Europe, dalam Islamic Banking and Finance, Butterworths Editorial Staff, London. hal. 43-52. 
memberikan jasa-jasa perbankan yang sesuai dengan syariat Islam.

\section{Tahapan keempat}

Tahap perkembangan keempat ditandai dengan pengembangan pendekatan yang lebih integratif dan sophisticated untuk membangun keseluruhan teori dan praktek ekonomi Islam terutama lembaga keuangan dan perbankan yang menjadi indikator ekonomi umat. Dengan demikian jelas bahwa proses evolusi dan embrio kegiatan keuangan dan perbankan dalam masyarakat Islam telah dilakukan oleh seorang individu untuk satu fungsi keuangan dan perbankan. Kemudian berkembang menjadi profesi jihbiz, yaitu seorang individu melakukan ketiga fungsi keuangan dan perbankan. Lalu kegiatan tersebut diadopsi oleh masyarakat Eropa abad pertengahan, dan pengelolaannya dilakukan oleh institusi, namun kegiatannya mulai dilakukan dengan basis bunga. Karena mundurnya peradaban umat muslim dan penjajahan bangsa-bangsa Barat terhadap negara-negara muslim, maka evolusi praktek keuangan dan perbankan yang sesuai syariah sempat terhenti beberapa abad. Baru pada abad 20 ketika bangsa muslim mulai merdeka, terbentuklah bank syariah modern di sejumlah negara dan insya Allah akan terus mengalami perkembangan.

Pada era modernis, konsep keuangan dan perbankan syariah yang tertuang dalam konsep ekonomi Islam mulai dirajut kembali untuk dimunculkan sebagai sebuah konsep ilmu teoritis maupun aplikatif. Pembagian mazhab alur pemikiran Ekonomi, keuangan dan perbankan muncul dalam tiga mazhab. Mazhab Baqir As Sadr, Mainstream, dan alternatif Kritis. Hal yang melatarbelakangi pembagian ketiga mazhab ini adalah adanya perbedaan pendapat akan adanya konsep apa dan bagaimana ekonomi, keuangan dan perbankan. Akan tetapi, belum secara pasti dapat dibuktikan bahwa aplikasi konsep dan teori ekonomi, keuangan dan perbankan di masyarakat saat ini adalah sudah cukup dinaungi oleh ketiga mazhab tersebut diatas.

Dalam bahasan ekonomi, keuangandanperbankankontemporer, fase perkembangan modernis terbagi menjadi dua bagian, yaitu:

a. Fasepertama(sebelumtahun1970an) kebanyakan sarjana ekonomi keuangan dan perbankan lebih condong pada pewacanaan pendekatan normatif dan teknis kelembagaan.

b. Fase kedua (tahun 1980) sarjana muslim lebih memfokuskan diri pada usaha merumuskan aspek filosofis dan metodologi ekonomi dan keuangan. ${ }^{13}$

Upaya pemunculan kembali ekonomi, keuangan dan perbankan ditengah masyarakat dunia dengan tawaran konseptual keilmuan dan sistem ekonomi dan keuangan yang seolah nampak baru mulai diupayakan secara masif semenjak abad modernis,

${ }^{13}$ Karim, Adiwarman. 2003. Sejarah P mikiran Ekonomi Islam, Edisi Kedua. Jakarta: IIIT Indonesia, hal. 26 
khususnya yang telah terjadi di Indonesia, ekonomi Islam telah terasa masif semenjak munculnya kegiatan keuangan dan perbankan syariah di Indonesia yang dipelopori oleh Bank Muamalat Indonesia. Dalam perkembangannya ekonom-ekonom muslim tidak menghadapi masalah perbedaan pendapat yang berarti. Namun ketika mereka diminta untuk menjelaskan apa dan bagaimanakah konsep ekonomi, keuangan dan perbankan syariah itu, mulai muncullah perbedaan pendapat.

Berdasarkan fenomena tersebut, banyak para ekonom-ekonom muslim yang mencoba memberikan solusi dari permasalahan yang terjadi pada perkembangan pemikiran fiqh keuangan dan perbankan, yang kemudian memunculkan mazhab-mazhab dalam ekonomi Islam. Pemikiran ekonom-ekonom muslim kontemporer tersebut dapat diklasifikasikan setidaknya menjadi tiga mazhab ${ }^{14}$, yakni:

a. Mazhab Baqir as-Sadr, Baqr As Shadr

b. Mazhab Mainstream; Umar Chapra, As Siddiqi, etc.

c. Mazhab Alternatif-kritis

Masing-masing dari ketiga mazhab tersebut telah memiliki ciri khas yang bisa saling berkonfrontasi, seperti halnya mazhab mainstream yang terlihat paling moderat karena sikapnya terhadap teori ekonomi konvensional yang tidak sematamata dihapus, melainkan dipilah

${ }^{14} \mathrm{Ibid}$, hal. 57 berdasarkan prinsip metodologi teori ekonomi, keuangan dan perbankan jika didapatkan sesuatu yang tidak salah dan dibolehkan atau dibenarkan maka hal itu dilaksanakan, dan apabila ada yang salah maka hal itu dihilangkan. Begitu juga sikapnya terhadap permasalahan pangkal dari sebuah teori ekonomi berupa scrachity (kelangkaan) yang titik tolaknya pada dasarnya sama, melainkan lebih pada pola distribusinya. Hal ini berbeda sama sekali dengan As Shadr, yang sampai tegasnya mazhab ini berpendapat bahwa jika ingin dinamakan dengan ekonomi Islam, seharusnya tidak perlu pakai istilah ekonomi melainkan dengan istilah yang berubah total yakni iqtishaduna. ${ }^{15}$ Permasalahan ini dikarenakan mazhab as Sadr tidak menyetujui jika permasalahan ekonomi adalah sama dengan konvensional, yakni pada kelangkaan sumber daya. Sebab menurut mazhab ini, pada dasarnya Allah telah menurunkan secara jelas ayat yang menegaskan bahwa sumber daya yang ada itu pada dasarnya sudah cukup, tinggal bagaimana manusia mengolahnya dan mendistribusikannya. Sedangkan mazhab kritis, lebih pada analisa mendalam mengenai hasil temuantemuan sistem ekonomi yang ada termasukekonomiIslamuntuk dikritisi kembali secara terus menerus.

Diantara ketiga mazhab ini, jika dikaji berdasarkan teori dialektika dan sebuah kesatuan metodologi bukanlah

${ }^{15}$ Baqr As Shadr, 2008, "Buku Induk Ekon mi Islam Iqtishoduna”, Ziyad, Jakarta, hal. 103 
tiga teori yang sebenarnya layak untuk menimbulkan klaim, sehingga pada akhirnya memunculkan konflik dialektika teori yang meruncing. Akan tetapi, dari ketiga mazhab ekonomi Islam tersebut, pada dasarnya memiliki sebuah kesatuan dan mampu untuk saling mengisi satu sama lain yang didasarkan dari peran teori yang diusung oleh masing-masing mazhab tersebut.

Seperti halnya kekurangan pada mazhab mainstream yang cenderung mudah disalah persepsikan sebagai ekonomi minus riba plus zakat dapat untuk kemudian ditegaskan kembali oleh mazhab As Sadr dan dikoreksi secara terus menerus oleh alternatif kritis. Teori pada dasarnya akan mengalami evolusi melalui pelestarian, inovasi, dan kepunahan, maka terdapat suatu proses evolusi dalam sejarah manusia. Proses ini ditandai dengan dua kecenderungan, yakni adanya keanekaragaman dan kemajuan. keanekaragaman mengacu kepada kenyataan bahwa jumlah dan aneka ragam masyarakat sangat meningkat, dan pola-pola adaptasi manusia semakin lama semakin berbeda-beda. Sementara kemajuan tidak mengacu kepada peningkatan kebahagiaan atau moralitas tetapi kepada perkembangan teknologi dan kepada perubahan organisasi dan ideologi yang terjadi bersamaan dengan perkembangan teknologi.

Dari ketiga madzhab yang ada (Baqr as Sadr, Mainstream dan alternatif kritis), di Indonesia muncul beberapa tokoh pemikir Ekonomi
Islam yang pemikirannya lebih kepada aktualisasi fenomena yang terjadi di masyarakat dan cenderung praktis dalam melihat ekonomi Islam secara umum, pemikiran ekonomi Islam versi Indonesia ini di kenal dengan Foundamentalis-IntelektualProfesional ${ }^{16}$. Tokoh-tokoh dari aliran Foundamentalis-IntelektualProfesional ini antara lain, Adiwarman Karim, A.M. Saefudin, Karnaen Perwataatmaja, M. Amin Aziz, Mohammad Syafi'i Antonio, Zainal Arifin, Mulya Siregar, Riawan Amin dan sebagainya.

Di Indonesia, fundamentalis yang memperjuangkan tegaknya ekonomi Islam dapat dibedakan menjadi dua kelompok, yaitu kelompok professional dan kelompok intelektual. Kelompok fundamentalis professional berorientasi pada praktek. Mereka merasa tidak perlu menunggu perkembangan teori Islam menjadi mapan, serta mencukupkan diri dengan "piranti" teori yang sudah ada, yaitu fiqh mu'amalah setelah dikonseptulaisasi. Golongan professional inilah yang berada di balik pendirian BMI dan bank-bank Islam lainnya.

Berbeda dengan fundamentalis professional,fundamentalisintelektual justru berorientasi pada teori. Mereka berupaya menyediakan bangunan teori-teori ekonomi yang kokoh terlebih dahulu sebagai dasar pijakan bagi terlaksananya ekonomi islam

${ }^{16}$ A. Dimyati, 2009, "Redefinisi Keillmuan Ekonomi Islam di Indonesia” Tulisan pada Jurnal Ekonomi Islam Iqtishady, Yogyakarta, hal. 5 
secara baik dan benar serta dapat diterima secara luas oleh masyarakat (ilmiah). Sekalipun demikian, dalam upaya membangun teori tersebut kelompok fundamentalis intelektual ini juga tidak sepaham, setidaknya dalam memandang ekonomi Islam mereka terpisah menjadi tiga corak (mazhab), yaitu mazhab Baqir asSadr, mazhab Mainstream dan mazhab Alternatif.

\begin{tabular}{|c|c|c|}
\hline Fase & \multicolumn{2}{|c|}{$\begin{array}{c}\text { Perkembangan Pemikiran } \\
\text { Ekonomi, Keuangan dan } \\
\text { Perbankan }\end{array}$} \\
\hline 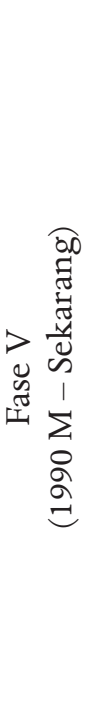 & $\begin{array}{l}\text { Adiwarman } \\
\text { Karim } \\
\text { A. M. } \\
\text { Saefuddin } \\
\text { Karnaen } \\
\text { Perwatatmaja } \\
\text { M. Amin Aziz } \\
\text { Muhammad } \\
\text { Syafi'I } \\
\text { Antonio } \\
\text { Zainal Arifin } \\
\text { Riawan Amin } \\
\text { Dan lain-lain }\end{array}$ & $\begin{array}{l}\text { Fouundamentalis- } \\
\text { Intelektual- } \\
\text { Profesional. } \\
\text { Foundamentalis } \\
\text { Profesional lebih } \\
\text { kepada aktualisasi } \\
\text { dalam praktik } \\
\text { Ekonomi Islam. } \\
\\
\text { Foundamentalis } \\
\text { Intelektual lebih } \\
\text { kepada aktualisasi } \\
\text { dalam teori } \\
\text { Ekonomi Islam. }\end{array}$ \\
\hline
\end{tabular}

Dengan demikian dalam perkembangan pemikiran ekonomi Islam, terutama madzhab-madzab pemikiran ekonomi Islam sudah menjadi wacana dan menjadi konsep dasar dalam setiap pemikiran dan pendapat dalam melihat ekonomi Islam. Begitu juga yang ada di Indonesia, perkembangan pemikirannya pun menjadi sangat berkembang dan cenderung tidak mengikuti madzhab yang telah mapan, akan tetapi memunculkan aliran atau boleh juga disebut madzhab Ekonomi Islam Indonesia menjadi landasan dasar pemikiran para tokoh ekonomi Islam di Indonesia.

\section{PENUTUP}

Keuangan dan perbankan Islam bukanlah temuan dari gerakan politik ekstrim Islam abad ini, namun bersumber dari perintah yang ada dalamalQurandansunnah. Keyakinankeyakinan pokok hukum Islam yang bersumber wahyu berkenaan dengan urusan muamalah ini merupakan bagian dari agama yang sama nilainya dengan kajian fiqh lainnya. Hukum Islam telah mengambil serangkaian ketentuan yang saling terkait dari kitab suci yang melarang pengambilan bunga dan praktek spekulasi yang tidak wajar. Pada abad pertengahan, kedua praktek tersebut dianggap sebagai perbuatan dosa sekaligus melanggar hukum, dan benar-benar dihindari. Praktek keuangan dalam bentuk Islam yang berumur ratusan tahun tersebut sebagia besar mengalami kemunduran selama kurun waktu kekaisaran kolonial Eropa, keitka hampir seluruh dunia Islam berada di bawah kekuasaan Barat. Di bawah pengaruh negara-negara Eropa, sebagain besar negara mengadopsi sistem perbankan dan model perusahaan yang terilhami Barat serta meninggalkan praktekpraktek perdagangan Islam. Dengan demikian, periode modern keuangan Islam dimulai ketika negara-negara 
Islam mendapatkan kemerdekaan setelah Perang Dunia Kedua.

Gelombang jati diri Islam yang lebih kuat telah memberikan dorongan positif yang lain bagi penerapan prinsip-prinsip Islam dalam keuangan dan perbankan. Karena jenuh dengan politik dan kebudayaan Barat, dan diilhami oleh kesalehan religius, sejumlah Muslim taat yang terus bertambah jumlahnya berusaha untuk menyesuaikan kehidupan mereka di dunia modern dengan ajaran agamanya. Berakhirnya kolonialisme dan munculnya trend keberagamaan telah merangsang kebangkitan kembali keuangan dan perbankan Islam.

Setelah menelusuri secara singkat sejarah praktek keuangan dan perbankan yang dilakukan oleh umat muslim, maka kita dapat mengambil kesimpulan meskipun kosa kata fikih
Islam tidak mengenal kata "Bank", namun sesungguhnya bukti-bukti sejarah menyatakan bahwa fungsifungsi keuangan dan perbankan modern telah dipraktekkan oleh umat muslim sejak masa nabi Muhammad saw sampai dengan masa modern.

Perkembangan praktek-praktek dari fungsi keuangan dan perbankan ini tentunya berkembang secara berangsur-angsur dan mengalami kemajuan dan kemunduran di masamasa tertentu, seiring dengan naikturunnya peradaban umat muslim. Dengan demikian, dapat dikatakan bahwakonsepkeuangandanperbankan bukanlah suatu konsep yang asing bagi umat muslim, sehingga proses ijtihad untuk merumuskan konsep bank modern yang sesuai dengan syariah tidak perlu dimulai dari nol. Jadi, upaya ijtihad yang dilakukan insya Allah akan menjadi lebih mudah. 


\section{DAFTAR PUSTAKA}

Adiwarman Karim, 2001, "Bankir Yahudi pada Zaman Abbasiyah", Ekonomi Islam Suatu Kajian Kontemporer, Gema Insani Press, Jakarta.

Adiwarman Karim, 2001, "Ketika Riba Menjadi Bunga”, Gema Insani Press, Jakarta.

Ahmad, Khursid. 2001. "Kata Pengantar" dalam Umer Chapra (2001), Masa Depan Ilmu Ekonomi: Sebuah Tinjauan Islam/The Future of Economics: An Islamic Perspective. Ikhwan Abidin Basri (terj.) Jakarta: Gema Insani Press.

As Shadr, Baqr, 2008, "Buku Induk Ekonomi Islam Iqtishoduna”, Ziyad, Jakarta.

Chapra, Umar, 2004, "The Future of Economic: An islamic Perspective", STEI SEBI, Jakarta.
Karim, Adiwarman. 2003. Sejarah Pemikiran Ekonomi Islam, Edisi Kedua. Jakarta: IIIT Indonesia.

Mr. Erik Trolle-Schultz, 1986, How the First Islamic Bank was Established in Europe, dalam Islamic Banking and Finance, Butterworths Editorial Staff, London.

Qardhawi, Yusuf, 1995, Daurul Qiyam wal akhlaq fil iqtishad al-Islamy, (Norma dan Etika Ekonomi Islam) oleh Zainal Arifin dan Dahlia Husein, Gema Insani Press, Jakarta.

Sami Hamoud, 1985, Islamic Banking, Arabian Information Ltd, London.

Sudin Haron, 1996, Prinsip dan Operasi PerbankanIslam, Berita Publishing Sdn Bhd, Kuala Lumpur.

Sudin Haron, 1997, Islamic Banking: Rules and Regulations, Pelanduk Publications, Petaling Jaya. 